and between different municipalities, such service-at-cost contracts can properly, in our judgment, be made only with the public service commission, and in such cases the provisions of the contract should apply in any particular community to the system as a whole rather than to its individual parts." That knocks out municipal control in Cleveland! It makes it impossible not merely in New England, New Jersey, and upstate New York, but in Pittsburgh, Detroit, Milwaukee, Minneapolis, St. Paul, the Kansas cities, and I fancy in almost every city in the country, big or little.

Thus we see that the corollaries of the recommendations and suggestions of the Federal commission, so far as the service-at-cost plan is concerned, lead us into a labyrinth of doubt upon every subject except the guaranty of capital and the restoration of the investor's confidence in street railway securities-and even there, although the general purpose is clear, we are not altogether sure of the practical result.

\title{
THE EFFECTS OF TAX LIMITATION IN OHIO CITIES
}

\author{
BY RAYMOND C. ATKINSON \\ Western Reserve University
}

Ohio still retains the uniform general property tax with a rigid tax limitation. Cities face financial ruin while rural and urban groups

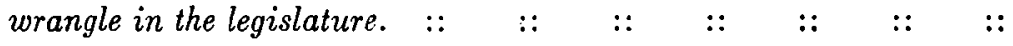

Probably the financial problem facing American cities has arisen in its most acute form in Ohio. Ohio cities have for ten years been laboring under the handicap inflicted by the so-called Smith 1 per cent law, which throttles down the tax revenue of municipalities to a point far below the present requirements of good government.

\section{THE SMITH ONE PER CENT LAW}

The Smith law was enacted in 1910 when the taxation machinery of the state was undergoing a general overhauling. Prior to that time property had been assessed at only a fraction of its actual value. In the reassessment of 1910 , however, an attempt was made to secure a 100 per cent valuation of real estate and to force out of concealment a larger amount of personal prop- erty. To reassure the taxpayers the legislature enacted a tax limitation of 1 per cent. Within the prescribed 1 per cent levy the greater part of the tax revenue of local governments and a considerable share of the state's income were to be obtained, with the exception that an additional levy might be imposed to meet interest and sinking fund charges upon debts previously incurred or which might thereafter be incurred by popular vote. As though this restriction was not sufficiently severe, the legislature inflicted a further check upon municipal extravagance. The total receipts of cities from taxation for 1911 were not to exceed the amount collected in 1910, and only a slight increase could be made in 1912 and 1913 after which the total was to remain stationary. Such a stupid attempt to stop the wheels of municipal progress 
can scarcely be imagined, yet it remained upon the statute books of Ohio for three years. Yielding to the pressure of city officials the legislature finally repealed that particular provision in 1913 , but the percentage limitation continued in force. A further modification was also secured which enabled cities by popular vote to raise the maximum tax limit to 15 mills. Beyond that point the tax rate might not go, except to meet certain emergencies such as floods and epidemics.

Fifteen mills may seem an adequate provision for municipal revenue, but it must not be forgotten that the city is only one of several agencies of government among which the 15 mills is parcelled out. The apportionment of the tax rate is entrusted to a county budget commission consisting of the auditor, treasurer, and prosecuting attorney, all county officials. The requirements of the state are first provided for, and needless to say, the budget commissioners see that the county receives second consideration. The requests of the school board usually come next in the order of preference, while the city, library board and other agencies of government have to be content with what remains.

\section{HOW TAX LIMITS WERE EVADED}

For a time cities sought to overcome the handicap under which they labored by failure to provide for the retirement of their bonds. Debts were refunded as they fell due. In this way deductions for sinking fund charges were kept at a minimum, and the revenue available for operating purposes was increased. Such a policy must naturally be short-lived. It was not only bankrupt finance, but in direct conflict with a clause of the state constitution as well. This practice continued, nevertheless, until the state supreme court in 1916 definitely declared that full provision for interest and debt retirement took precedence over all other expenditures. In 1917, the first year that this requirement was observed, the operating revenue of the city of Cleveland derived from the general property tax fell off almost one-third, and there was a corresponding increase in the levy for the sinking fund. This resulted in a reduction of about one-fifth in the total operating revenue of the city. According to statistics published by the state auditor in 1917, if all cities had met the interest on their bonds and the entire cost of debt retirement from taxation, debt charges alone would have exceeded the total tax revenue of the 80 cities of Ohio by $\$ 180,000$. Naturally full compliance with the supreme court's decision was impossible. Cities were confronted with the alternative of refunding their bonds as they fell due or borrowing money for running expenses. The large cities compromised by doing both. In that way immense floating debts were incurred which cities were utterly incapable of paying, and the legislature was forced to authorize the issuance of deficiency bonds.

Other factors also played a part in the creation of this situation. In the first place the assessment roll for the general property tax did not keep pace with expanding governmental needs. Revaluations were infrequent and a 100 per cent assessment was seldom actually secured. Another important factor was the accelerated growth of municipal activities after 1910. In many instances the state itself imposed additional burdens upon cities. Large expenditures for water purification and sewage disposal were ordered by the state board of health. Heavy debts were also incurred for street improvements and public buildings, thus in- 
creasing the fixed charges of local government. Finally a modification of the state liquor license regulations reduced revenue from that source.

\section{FLOATING DEBTS PERIODICALLY} FUNDED

As a result of this combination of circumstances Ohio cities have for several years been amassing floating debts which the legislature has periodically permitted to be funded with deficiency bonds. Cleveland began to run behind as early as 1915 , even before the supreme court decision as to sinking fund requirements. The other principal cities have one by one fallen into line. In Dayton the city manager by vigorously cutting expenditures avoided the difficulty until 1917 . Springfield has escaped with a deficiency of only a few thousand dollars, while Sandusky has an actual surplus. Most of the non-manager cities have been less fortunate. At the close of 1919 , Cleveland had outstanding \$7,000,000 of deficiency bonds, almost one-tenth of its total debt, and has since been compelled to issue $\$ 5,750$,000 additional bonds to meet running expenses. (The estimated tax income of the city for operating purposes will scarcely more than cover the cost of the police and fire departments alone.) In Cincinnati a floating debt of $\$ 1,340,000$ was funded in 1917 , and a deficit of about $\$ 3,000,000$ is anticipated for the present year. Columbus was forced to issue $\$ 560,000$ of deficiency bonds in 1919, but hopes to live within its income in 1920. In Toledo, a more rapidly growing city than Columbus, $\$ 850,000$ of deficiency bonds have already been accumulated, with the likelihood of a large floating debt at the close of the current year. Nor is this condition confined to the larger cities alone. Some of the smaller municipalities have deficits which are almost as burdensome in comparison with their tax revenue.

It might be supposed that such financial straights would lead to greater administrative efficiency. Certainly the necessity of economy is apparent. It is very doubtful though whether there has been any such result. True there has been a vigorous paring of governmental services, but that the work which is done is more efficiently handled is extremely unlikely. The spectre of bankruptcy does not necessarily prevent waste. The very impossibility of living on the existing income together with the recognized necessity of reducing services exerts a blighting influence. A hopeless, don't care attitude on the part of officials is not unnatural. Furthermore the lack of funds furnishes a ready excuse for inefficiency which the citizen cannot easily refute.

\section{VOTERS DIVIDED ON RELIEF TO BE PROVIDED}

Confronted by this situation, what remedies have been applied? The truth is that only makeshift measures have thus far been adopted. The Smith law has from the start been attacked by the larger cities which realized the impossibility of performing their functions with the limited income available. The act has, on the other hand, been popular with the rural element which has a majority in the legislature. The country population cannot understand the immense financial requirements of the greater cities, and attributes their difficulties to extravagance, inefficiency and a failure satisfactorily to administer the general property tax. There is also a widespread feeling that a tax of 15 mills on a 100 per cent valuation of real estate is heavy enough and that additional 
revenue should be obtained from other sources. Consequently until the present year all attempts to break down the Smith law limitations have met with failure.

The validity of the claim that the burden upon real estate should not be further increased has been recognized by tax reformers. The financial difficulties of Ohio cities are not simply the result of tax limitation but of inadequate sources of revenue. How sufficient income can be secured through the general property tax without at the same time overburdening realty is a problem which has not been solved. Ohio relies chiefly upon the general property tax. In fact, it cannot do otherwise so long as the constitution remains unaltered, for it specifically provides that all taxation shall be by uniform rule. The attack upon the Smith law has, therefore, involved the question of classification of property and a revision of the whole taxation system of the state. The fight for classification thus far has not been successful. A classification amendment was submitted to referendum in 1918 and again in the fall of 1919 . In 1918 it received a majority, but was later invalidated by the state supreme court. A second amendment, approved at the same election, according to the court, conflicted with the principle of classification, and inasmuch as the second measure obtained a larger popular majority the classification amendment had to give way. Another proposal was squarely defeated in 1919. Throughout the fight the farmers have been hostile to the plan and the state grange has led the opposition. The idea of uniformity in taxation seems to have a firm hold upon the rural electorate, in spite of the manifest injustice of the general property tax to the farmer in practice. A general feeling evidently prevails that the separate taxation of real and personal property would result in even greater discrimination against the former. Whenever the general property tax has been attacked, the farmer has parried with talk of more stringent administrative provisions to force intangibles out of hiding. It would seem as though Ohio, at least, had experimented sufficiently with tax ferret legislation. Until the farmer changes his views, the financial ailments of Ohio cities cannot saisfactorily be treated.

The legislature has shown little disposition to work out a solution, although the problem has been before it for several years. Investigations have been made and cities have been allowed to explain their plight, but there is no painless method of extracting revenue for the government, and legislators shy at measures which too obviously increase the tax burden. Until the last session the legislature confined itself to temporary expedients in the form of acts authorizing the funding of current debts. It was hoped that these measures would tide cities over the war period. The continuance of high prices after the armistice, however, made it clear that a day of reckoning must come. Cities cannot long be financed with deficiency bonds.

Unfortunately the legislature and the governor are of opposite parties. The governor is a Democrat, while the Republicans have a majority in both houses of the assembly. Under such conditions little co-operation can be expected. At the opening of the last session the governor was glad to urge upon the legislature the solution of the taxation question, but quite unwilling to present a plan of his own. He probably felt that it was good political strategy to allow the Republicans to demonstrate their inability to handle the problem and to cast the onus upon his opponents. The assembly lacked 
competent leadership and floundered sadly. When the session closed the governor denounced the failure of the legislature to reconstruct the tax system, and the Republican state committee retaliated by condemning the lack of leadership on the part of the governor. Thus the buck was passed.

\section{THE GARDNER ACT A MAKESHIFT}

In spite of its shortcomings the session was not entirely fruitless. The enactment of a heavy automobile license $\operatorname{tax}$ and a new inheritance tax from which the local government receives one-half helps considerably toward replacing the former liquor tax. The way was also opened by which cities may vault over the Smith law limitations. A new measure, the Gardner act, allows taxing districts by popular vote to place their interest and sinking fund charges outside the 15 mill limit. A number of cities are now preparing to submit the question to referendum. If approved it will grant much-needed relief to municipal treasuries by permitting a considerable increase in the rate of levy for operating expenses. In many cases it will double the operating levy. The general property tax rate will be very much higher and the burden upon real estate decidedly severe. For that reason some difficulty may be encountered in securing popular approval of the change.

The Gardner act is only a makeshift remedy at best, for Ohio must soon overhaul its entire system of taxation. A higher general property tax rate will inevitably cause complaint and may hasten a thorough revision of the system, but before this can be undertaken a constitutional amendment will be necessary. Considerable sentiment has developed in recent months in favor of an income tax. It has the endorsement of the state grange and was pressed by the rural element in the last session of the legislature, but the movement soon struck a snag. Banking interests were unwilling to accept an income tax so long as personal property remained subject to the general property tax. It was feared that an income tax might force the disclosure of bank deposits, and thus expose them to the high general property tax levy as well, which would almost be confiscation. This encounter merely serves to re-enforce the conviction that a classification amendment is a fundamental part of any constructive tax reform in Ohio.

While the prospect of modernizing the taxation system is considerably brighter, it is only because the financial condition of municipalities and school districts has become intolerable. The ten-year struggle of Ohio cities to live upon an inadequate income has been little less than tragic. If anything could prove the utter folly of tax limitations, Ohio's experience with the Smith one per cent law ought to be sufficient. The rural legislators in their kind endeavor to save cities from their own rapacity have nearly bankrupted a number of municipalities and have impaired services in many others. One need not be a socialist to realize the futility of such efforts. The activities of a city must inevitably grow more rapidly than the general property tax duplicate, and if progress cannot be bought with current revenue it will be purchased with bonds against the future. 